\title{
Research on the Emotional Direction of Mourning Poetry in the Song Dynasty
}

\author{
Xinxin Zhang \\ Weifang University of Science and Technology, ShanDong ShouGuang, 262700,China.
}

Keywords: Song Dynasty; The song dynasty; Lament; The generalized lament; Emotional point.

\begin{abstract}
This paper mainly studies the emotional word Memorial in Song dynasty. To mourn the death of a spouse or a lover, the dead wife's emotional attitude is taken and solemn, on the death concubine is Yizhuang also "color", on the dead prostitute's attitude is both sensual. Friends of the CI are to show a deep affection. To pay tribute to the martyrs, emotional point of focus is the world which is full of admiration, pride of a cavity.
\end{abstract}

\section{Introduction}

Grieve for 2500 years ago, in the "book of songs". The literati Monody is for mourning over the singular love wife, so narrow elegiac poems refers to those who mourn a deceased wife poem. Generalized grieving poems should also include other friends and mourning poems paying homage sages martyrs. During the Song Dynasty, ci poetry is very prosperous, lament also made remarkable achievements, which has had the profound influence of the later generation, it is worth of careful study.

\section{A sincere tribute to a lover or lover.}

During the Song Dynasty DaoWang word masterpiece forest, in broad terms, these words of lament object includes to mourn the death of a spouse or lover, mourning friends, to pay tribute to the martyrs there.

Unforgettable virtuous wife. Conjugal love, together always since ancient times people are located in pursuit of the highest realm of love. "The Book of Songs - Bei Feng -" drumming in there "and that you always know the right thing. Keep your hand, and son ". However, the world may not be always the best, Xiangruyimo couple total party will first pass away, so life and death of farewells with infinite pain, mourning the infinite grief decline inevitably coupled to the widow. The wife, husband grieving to express compassion work will come very naturally to produce.

The Song Dynasty tribute to the most famous dead wife, Su Shi's "Jiangcheng Zi" (ten years of life and death to boundless) and he cast the partridge day - death Tong "(a non changed gate everything).

At the age of nineteen Su Shi married Wang Fu, two people love peace, cherish affection. Wang Fu Su Shi with the officer in the capital, unfortunately in the song Yingzong Zhiping two years (1065) died in May. "Jiangcheng $\mathrm{Zi}$ " is remembered as the good wife for temperature. Sue Shi for the dead wife Wang epitaph "wrote:" at the end of the prince married, parents, both married, thing my first gentleman, lady first, tailor like Su smell.... Knowledge Book...... Min and quiet. From Shi Guan Yu Fengxiang, Shi Jun has something on the outside, don't know the details...... What kind of knowled ge have more audible." Wang $\mathrm{Fu}$ is not only very filial piety, make all-out efforts serve parents in laws, but also numerous exhortations to her husband. For such a respectful, educated wife Tian $\mathrm{Su} \mathrm{Ci}$ ", certainly not thinking, since unforgettable". Not to mention in this decade. Dongpo for opposing Wang Anshi and suppressed, though depressed, the predicament of life, of course, will miss you more, my dead wife. Trouble, poets should be the suffering of the heart to the dead wife talk, so Youmeng "returning", see "Xiaoxuan window, is dressing" wife. The pair met, not only "whispers of love 
affection, care, tears of sorrow". "Speechless", actually includes the thousands of words, into the of career hardships of lament and the wife Wang Fu like Su "of praise.

Although he Zhu's song Xiao Hui after the Sun family, and very talented, but his life was an underling. His wife is the daughter of Zhao song imperial clan, her life frugal housekeeping, and he Zhu share sub. 's joys and sorrows, no regrets. The Partridge day - death Tong "in Brideshead Revisited, memories and dead wife cultivated in a long-term share of the joys and sorrows of life deep love, to express the deepest of Zhao's miss. The whole poem, "empty bed lying to the south window rain, who are burning the midnight oil fill vests" the climax of the lyric of this sentence is also the most touching point. The author is only a few words in front of us philandering a sad sight. Already in Liangbinbanbai poet was lying alone in the empty room, listening to the rain beating against the windows sound, by the thought. His wife passed away, and who would be on their own in the middle of the night burning the midnight oil to sew clothes? This sentence to trivial things and details of the plain, wife of Zhao industrious virtuous and Xiangruyimo between husband and wife and loving to read a Diwan Qijue, filled with emotion.

Qing Chen Ting Zhuo said: "Fang Hui words chest eyes, otherwise a sad that no source", the said in addition to his long runner underling, his wife passed away in death is also a very important reason.

Sue Shi, He Zhu, mourns for more. The poet Liu Kezhuang mourning for his dead wife Liu's four song "Forestsong" stands for. Li Kezhuang and Mrs. Lin section between very deep feelings, two people live side by side for 19 years is Mendanghudui a loving couple. Lin's intellectual, house well, popular poets respect. The poet had "epitaph" in the death chamber praised her: "You have sex. Loyalty and filial piety are dark and with my student center". In the face of state and individual small risk to, Lin Festival advised husband not to hinder, tolerance, Dali, visible the charactera, experience does have some attractions. grading fifteen years (1222), Liu Kezhuang wives went to Guilin, in a tour of the Lijiang River in distress, "girder break Zhou Xuan, dangerous in the twinkling of an eye", Lin Festival calm, there is no terror volume, Ke Zhuang again was touched her. This will be the first time year (1228), "Lin bitter spleen diarrhea, bait Dan Huangya continues", Keranershi, only thirty-nine years old.

Because of his wife's death, Liu Kezhuang is very painful, after two months, "falling plum poem case" dismissed from office in return for, more miserable, back Pu via Fuqing, wrote the first two word Memorial, to the first and second the feng-ru-song - Fuqing road ", for example:

Return to the saddle still want small hover. Adversity difficulty. People say wine is the elimination of worries. Rest, let the gold jar Nai disease. The bleak Daoyi, desolate feelings for drum. Breeze Lin far cry. Wild shop still open. Amorous only is the shadow before the lamp, accompany this Weng, go to come together. Hotel owner asked, this time is back to childhood as before.

"Bleak Daoyi, bleak drum for feelings, this sentence is obviously in gratitude for a virtuous wife. Today's "dismal" because his wife died. When the wife is alive, when the autumn wind blows, the season will be for the poetic garment, should be in "Daoyi" time will ci poetry Daoyi, hardworking and virtuous is not self-evident. After the first two "feng-ru-song" entitled "guanaco to Shitang chase and fifteen years ago rhyme", trigger points as the first two pieces, it is still the "residual more", "bleak" when, literally although not involved hard-working wife virtuous, but between the lines are always exposed this meaning.

These words are Song Dynasty poet innermost feelings sincere feelings to express, in the era that the female is regarded as the accessories and their wife sincere touching feelings are undoubtedly a very valuable. From these words, we can see, mourning his wife's words are mostly poets grieving wife industrious virtuous, emotion is very solemn.

The female poet of mourning husband, the husband died after their dis mal feeling. Different quantity numerous mourning wife for that song mourning her husband in the words of one of the few, rendered also only Li Qingzhao and Sun Daoxuan works. Li Qingzhao's love and marriage were very happy, her husband Zhao Mingcheng and like-minded, like-minded, happy family life. However, shortly after the Song Dynasty, Li Qingzhao was a heavy blow to the country, the death of her husband, 
was full of deep sorrow. "Wild goose" is mourning her husband. The husband died after his death in tears sad plight.

Rattan bed paper accounts toward sleep, say no, just. Agilawood intermittent furnace jade cold, with my feelings like water. The San Nong, Mei heart broken, how many spring tour. The wind rain Xiao Xiao, and rush, tears of thousands of lines. Energy-saving, heartbroken and who lean against? A twig, heaven and earth, no one can send.

"The furnishings rattan bed" in Song Ci, mostly bleak scene of burnout. NIKKO, lay crosswise on the bed, it is in his portrayal of the lonely boring. Write "wind and rain rustle, a nd reminders, thousand lines of tears" is not within the drizzly rain, next stop, door poet idly, tears thousands of lines. To tear in the rain, the rain lining tears, Huangruo poet in the sound of slow "wrote:" Ind us Gengjian drizzle, to dusk, bit by bit. In this article, how an anxious word?" This sentence is very vivid picture of her husband died. His tears are suffering great agonies of the mind. The term that "heaven on earth" tries to write the searching of love. "No one can send" tries to write the lost feeling.

Sun Daoxuan is a female poet after Li Qingzhao, her thirty year old widowed, Shouzhi to end. The life of the word rich, but the old age is burned with fire. "Drunk Sixian" is among the first few words she left, but she is the most praised his words. The second half Que "the past ten years long pin setting, in a hurry. Nian Yunxuan a dream, looking back spring empty. Cai Fengyuan, Yu Xiao cold night, quietly, infinite hate. With yellow dust, long buried jade, a tearful Dongfeng "comparable to the word li.

Unforgettable beauty and death concubine dance. Mourning for his dead wife for her husband or, is with the wife or husband of love and respect, is very solemn. This kind of emotional attitude and words of people mourning for concubines is very different. Grieving the death of concubine $\mathrm{Ci}$, most frequently involve beauty dance, occasionally and virtuous. With Wu Wenying to Hangzhou dead concubine DaoWang word "purple is spring" as an example:

Fall south yarn. And the light dizzy night cools, open curtain air roll. At twilight leaves blowing, dry autumn short morning dew. The moon was painting. As you are well off the road, shut. Under the shadow of fog, unless, the empty mirror is not seen. Annex. Qiuniang at knowledge, like people, in the hope of doubling wave coagulation. Old color incense, idle rain cloud conditions eventually shallow. Who really can draw pictures, only to see plum, frequency. It will flower pear with sleet, scattered dream.

This is a poet in the fall of a year. In Jingkou suddenly encountered a perish with the concubine looks very similar to the geisha, touches the chord of emotion nor write.

"Fall south Yan", with his concubine Yu Dian Luzhu, and charming light. "Painting" to describe the graceful and beautiful concubine modality; "fog bus" refers to the beautiful concubine hair fluffy bun. "At first glance quitting knowledge, like people, in the hope of doubling wave coagulation", the surface is written Jingkou geisha beauty, the actual writing dead concubine beauty.

\section{Affectionate friends mourn for}

Removal of the memory of a loved one or a lover's lament for and lament CI in the Song Dynasty occupied should be the most prominent is a memorial to the word to friends as. Fine tradition of the Chinese people has traditionally been fond of making friends, treasure the friendship.

Reverence and miss to the friends of the teachers. Ou Yangxiu is Su Shi's mentor and leader, in the incentives, Sue's father and son in the world. Song Shenzong Yuanfeng two years (1079) April, third times after the life of Su Shi Ou Yangxiu in Yangzhou when the hall. At this time Su Shi and his mentor Ou Yangxiu closing time has reached nine years, and Ou Yangxiu has been dead for eight years. Coincides with their own political situation are difficult, Su Shi to revisit, cherish the memory of mentor for the song "Xijiang Yue - pinpointing, naturally recalling thousands of emotions.

"Ten years old sent, on the wall of the swift movement of calligraphy" and "old silo" is Su Shi's honorific to mentor Ouyang Xiu, which contains not only is mourning, is revered, the author from the 
bottom of my heart to the teacher also friends of the friends of respect and affection. "On the wall of the snake" means is 1056. Liu Yuanfu served as the magistrate of Yangzhou, Ouyang Xiu wrote the DPRK measures - pinpointing, a word you bask. The European public has been on the wall of pinpointing cents to, but still with the poem he had written.

On with the DPRK officials, miss friends the same political vie ws and lament. Huang Tingjian, Qin two and Chao Bu Zhi and Zhang Lei were called "the four bachelors". Owing to the impact of the Northern Song Dynasty struggles, their political and teacher Su Shi together, life with Andrew bumpy, mostly on the final. When Qin Guan banished to keep state died of depression after, Huang Tingjian and derogatory Yizhou, Taoist Hengyang, see Q in Guan manuscripts "Chiaki years old" word, mixed feelings, therefore and the words "Chiaki years" to the sustenance of bad thinking.

The word writes on toward the official joy. Judging from the back towards the future: "fly ride rolling, Ming Ke broken", written after they go together ride Benz pleasure situation. "Yan drum off" in two sentences, you can imagine, they tipsy, on state affairs, talks poems and articles, if their teacher $\mathrm{Su}$ Dongpo here, the atmosphere will be more active, must be Zhuang harmonic complex, talking about the wind. "Heavy feeling, 10000 ares waves bead heavy sea" this sentence is the whole word phrase, embodies poet friends mourning a somber mood. But also reveals the indignation of political persecution.

\section{The sad words of Yingjie dripping mourning}

When our spirits and memorial Yingjie depart from the world for ever after, pay homage to the souls of the works will appear in an endless stream. In Song Dynasty, there is not any lack of this kind of grief and indignation dripping DaoWang chapter.

For the hero Wu misses, worship and admiration. Liu Xin school is patriotic poet, advocate the anti gold salvation, restore the central plains. He had great admiration for the national hero Yue Fei, for "Kim's anti six had to pay the state song" sake. Poets praised prefixing gold to serve the country's performance, expressed deep miss and the infinite respect. The lines are full of such Wuguo gnash one's teeth in hatred and to the imperial court of the appetite for adventure over the love of ease of strong dissatisfaction. Yue Fei is located in the early years of the Southern Song Dynasty famous, once on the battlefield of anti gold established illustrious deeds, but scum of the nation, the traitor Qin Hui kill. Later, when the Song Xiaozong, Yue Fei's grie vance rehabilitate, restore the original office. Made or become better. The temple is currently West Lake temple. This poem is Yue Fei's tribute to him, and it is a memorial song.

For the writer scholars sigh mourning be frustrated for all one's talent. Jia Fu, the famous politician and writer of the Western Han Dynasty, Jia Yi. He was 18 years old in the county for two years after the fact, is the Han emperor called Dr., within a year was promoted to the doctor. At that time, some major policies and regulations enacted, issued by the hand of Jia Yi. Emperor in order to give full play to his talent and was ready to promote him "Duke", but was opposed to veteran minister, said he "young beginner specifically want to monopolize power, chaotic interlocutor", was demoted to Changsha Wang Taifu, so future generations Title Jia Fu. Yang Guanqing, the Bu operator - Qiu late set Du sentence hanging Jia Fu cloud:

People did not catch on Gufen Jia Su, 's pen. The color of this romantic surviving which was not regret. Desolate side near Changsha, secluded autumn would do. Long the hero tearful. God asked difficult.

Words que narration of Jia Yi life sufferings, highly praises the "literary talent", and lower express Changsha nostalgia, the expression of Jia Yi humbled die mourn and indignation. Begins with the words "mankind asthma not sue. Jia pen on solitary indignation" two. The author's attitude is clearly showed on $\mathrm{Yi}$ "mankind asthma not sue and repeatedly on the sparse eloquently of the abuses in the praise. "Sorrowful near Changsha, secluded autumn will do" these two like punning refers both to the 
Jia Yi was demoted when near Changsha "the sorrowful, also contains author at the moment the whereabouts and inner feelings.

\section{Conclusions}

It is the living word memorial for the dead deepest yearning. The poet is the world of the most painful the most sincere feelings. In memory of a loved one or a lover's words with fully feelings between husband and wife comfy and unforgettable love, from friends to grieve the words. It can be also seen that the "life was a confidant sufficient" generously deep sigh; from mourning martyrs of the works, it is the elder martyrs deepest reverence and on the country's matchless love feeling. But no matter what kind of emotional point of lament, implied meaning is not only "mourn", the author expresses them in the memory of their ancestors at the same time, more is combined with their own feelings, lamented what had happened to her. It will be unforgettable, enduring deep mourning and humans affair difficult life emotion mingles write, but also deepens the theme of mourning.

\section{References}

[1] Guizhang Tang. The whole song ci [M]. Beijing: zhong hua press, 1965.

[2] Hangpei Yuan. History of Chinese literature (volume 3) [M]. Beijing: higher education press, 2005.

[3] Jigao Ma. (c) of the ancient Chinese literature [M]. : hunan literature and art publishing house, 2006.

[4] GuoenYou. History of Chinese literature (3) [M]. Beijing: people's literature publishing house, 2005.

[5] Shi Su. His essays corpora (ZhongCe) [M]. Beijing: China today press, 1996.

[6] Jun Shen. Chinese past dynasties zhen then extract (bottom) [M]. Beijing: the guangming daily press, 1998.

[7] Qiaobin deng. Features and life, the introduction [M]. Shanghai: Shanghai ancient books publishing house, 2001.

[8] Yupu Zhang. Song dynasty lament ci as [J]. Journal of jiangxi normal university (philosophy and social sciences edition), August 2002, 35 (3).

[9] Xinquan Luo. Dao clothing, desolate feelings help. Southern song dynasty men lament word is virtuous, noble and pure theme [J]. Journal of xuzhou engineering institute, 2009.

[10]Wen Liu. song dynasty lament the idiomatic word images [J]. Journal of jinan university college of liberal arts. 